\title{
Units of translation adopted in Persian term-formation
}

\section{Unidades de tradução adotadas na formação terminológica persa}

\author{
Rasool Pasha Abgarmi* \\ Vida Shaghaghi*
}

\begin{abstract}
Two trends exist for Persian term-formation. In the first method known as calquing, words are rendered morpheme by morpheme. Thus, the unit of translation (UT) is a morpheme. In the second method known as conceptual equivalent-finding, the definitions of words are considered and the UT is a word. The present study was designed to identify which of the two UTs was more favored in Persian termformation. To this end, 40 English prefixes were studied in 2354 English words together with their Persian equivalents approved by the Academy of Persian Language and Literature (APLL) as the official term-formation agency in Iran. It was noticed that calquing was more frequent, i.e. morphemes were more frequently considered as UTs. Moreover, strategies of translating prefixes were introduced and examined in both methods. In conceptual method, prefixes were ignored and not translated morpheme by morpheme. However, in calquing, English prefixes were translated into Persian prefixes or lexemes.
\end{abstract}

Keywords: unit of translation, term-formation, prefix, conceptual equivalent-finding, calquing.

\footnotetext{
"Master's Degree from the Allameh Tabataba'i University.

** PhD from the Allameh Tabataba'i University.
} 
ABgarmI, R. P.; SHaghaghI, V. - Units of Translation Adopted in Persian Term-formation

Resumo: Existem duas tendências para a formação terminológica persa. Na primeira, método conhecido como decalque, palavras são transformadas morfema por morfema. Assim, a Unidade de Tradução (UT) é um morfema. Na segunda, método conhecido como achado-equivalente conceitual, as definições de palavras são consideradas e a UT é uma palavra. O presente estudo foi desenhado para identificar qual das duas UT foi mais favorecida na formação terminológica persa. Para este fim, 40 prefixos em inglês foram estudados em 2324 palavras em inglês e em conjunto com seus equivalentes persas, aprovados pela Academy of Persian Language and Literature (APLL) como agência oficial de formação terminológica persa no Irã. Percebeu-se que o decalque era mais frequente, ou seja, morfemas eram mais frequentemente considerados UTs. Além disso, estratégias de tradução de prefixos foram introduzidas e examinadas em ambos os métodos. No método conceitual, prefixos foram ignorados, e não traduzidos morfema por morfema. No entanto, no decalque, prefixos do inglês foram traduzidos para prefixos do persa ou lexemas.

Palavras-chave: Unidade de Tradução (UT), formação terminológica, prefixo, achadoequivalente conceitual, decalque. 
ABgarmI, R. P.; SHaghaghI, V. - Units of Translation Adopted in Persian Term-formation

\section{Introduction}

Term-formation deals with the small components of language known as terms. To put it simply, words are more general than terms. This means that words are identical to an umbrella term that embraces terms inside. Sager (1990) interprets words as items in the lexicon of a special language, which have general reference and are not specific to any discipline.

Persian term-formation is officially conducted by the Academy of Persian Language and Literature (hence, APLL). APLL was founded in 1935 in Tehran as the only official Persian language academy, authority, and regulatory body in Iran. It aims to conduct academic linguistic researches on Persian language and keep its originality and integrity as the common and official language of Iran. It also attempts to reinforce, develop, and equip Persian language in a way to meet the increasing cultural, scientific, and technical needs in the field of Persian language and literature. More importantly, APLL has the mission to eliminate dispersions among cultural and research centers over Persian language by coordinating linguistic efforts and researches. As such, it monitors and determines some criteria for termformation to be observed by translators or perhaps lexicographers in confronting new terms.

The term-formation council of APLL is composed of over 60 specialized groups. Within each of these groups, there exist some experts who, along with other members, find equivalents for foreign terms in their special fields such as physics, medicine, etc. Thus, the source words adopted in Persian termformation belong to different kinds of disciplines. The selected lexical items for the present study are not bound to a special field and include terms from several disciplines. Consequently, it would be much appropriate to use term and term-formation in our case.

The unit of translation (hence UT) in translating words from English into Persian would either be a morpheme or a word. This means that there are two 
ABgarmI, R. P.; SHaghaghI, V. - Units of Translation Adopted in Persian Term-formation

UTs considered for translating words: morphemes and words. Morphemes are either free or bound. Bound morphemes are basically of two kinds: affixes and roots. English language makes ample use of affixes for derivational termformation. In fact, derivation is the most employed procedure for termformation in English (YULE 2010). Persian, however, resorts to different procedures for translating such affixes of English words (KHODABAKHSHI 2009). This means that only in some of the words the UT is a morpheme and only some of the prefixes are translated into prefixes in Persian. For translation of other words, a word is normally considered the UT. In the present study, we attempted to investigate the translation of English prefixes into Persian by APLL. Different procedures for translating English prefixes are further studied. All this was done to determine which one of the two UTs, namely morpheme and word, is more frequent in Persian term-formation.

\section{Background}

The act of translating usually involves choosing one or more UTs. As Shuttleworth and Cowie (1997) suggest, this is done to determine the linguistic level at which the translator wishes to analyze the source text (hence, ST). Scholars have observed UTs at different ranks. In the earlier decades around 1950, structuralists adopted UTs at lower ranks, such as morphemes and mainly, words. From 1960s onward, translators or researchers focused on UT at ranks higher than word, i.e. phrase, clause, sentence, text, and even culture, after the cultural turn. It can be easily noticed that smaller UTs, such as morphemes, have usually been ignored. Translations have rarely remained at lower ranks than words so as to take morphemes into account. As Lehrer (1995) suggests, semantic units such as morphemes are given little attention in term-formation. Vinay and Darbelnet (1995) even reject the notion of words as UTs (quoted in MUNDAY 2008). Moreover, as the researcher 
ABgarmI, R. P.; SHaghaghI, V. - Units of Translation Adopted in Persian Term-formation

examined the MA and PhD theses in the universities of his country, only few studies had been carried out to consider words or morphemes as the UT.

Nevertheless, a lot of attention is given by terminologists to morphemes, since those are the smallest units of language. In fact, termformation based on the analysis of morphemes is of paramount significance in the translation of terms and modern Persian term-formation (TAJVIDI 2005). Thus, taking words or morphemes as the UT is indispensable as far as termformation is concerned simply because there are two ranks observed in termformation: word and morpheme. Following, some instances are presented even from languages other than Persian to illustrate the importance of morphemes and words as the smallest units of language and the significance of morphological analysis in translating words.

Analysis of morphemes was employed as early as $9^{\text {th }}$ century A.D. by AlKindi in his translations of philosophical terminology from Greek into Arabic (BADAWI 1986). He analyzed the derivational structure of Greek words to offer Arabic translations for them and sometimes resorted to other translators to describe the structure of Greek words to him. Whatever his intention from such an analysis, Badawi believes such morphological analysis in translating words is used even today in translating technical terminology. Morphemes are also specifically addressed by Casagrande (1954) in his linguistic types of translation (quoted in SHUTTLEWORTH AND COWIE 1997). He defines the aim of this type of translation as identifying and assigning "equivalent meanings to the constituent morphemes of the source language" (94). In linguistic translation, ST segments are rendered sequentially into target language (hence, $T L$ ) units and the structural form is of paramount importance.

Based on the foregoing, taking morphemes as UT is fundamental to the study of term-formation strategies, particularly derivation and compounding. Thus, the primary focus of the present research was to find the extent to which morphemes are used as UT in term-formation. The present study is perhaps the first one specifically focusing on UTs adopted in term-formation 
ABgarmI, R. P.; SHaghaghI, V. - Units of Translation Adopted in Persian Term-formation

since words or morphemes are rarely considered UTs. This demanded a study on the term-formation methods in Persian.

\section{Persian term-formation methods and UTs}

The present study adopts the strategies offered by the APLL for equivalent-finding. It is remarked in A Collection of Terms (TERMINOLOGY DEPARTMENT 2014) that there are two methods to find equivalents for English words:

1. Conceptual equivalent-finding: In this method, the focus is on the definitions and meanings of the English words as a whole, ignoring their structures.

2. Calquing: In the second method, the emphasis is on the structure and the constituents of the English words. In other words, every meaningful unit in the foreign word is replaced by a meaningful unit in Persian.

It is to add that in each of the two methods, term-formation is done through one of the term-formation patterns. In a study conducted by Pasha Abgarmi (2015), the two term-formation methods were examined in detail and strategies for treating English prefixes in Persian term-formation were introduced and investigated.

Tajvidi (2005) calls the above-mentioned second type of equivalentfinding the analytic-compositional method and suggests that it has been the most frequent equivalent-finding strategy in the recent decades. He offers this name because in this method, first, the word is analyzed to its morphemes and having found the equivalents of morphemes, they are combined. This method is frequent since both English and Persian languages are analytic. As it was mentioned in the background section, the analyticcompositional method has a long history in term-formation. 
ABgarmI, R. P.; SHaghaghI, V. - Units of Translation Adopted in Persian Term-formation

Considering the UT, it could be concluded that in the first method, the UT is a word since the meaning of the whole word is taken into account and the constituents are ignored. In the second method, the UT is a morpheme because the meaningful units of words (stated in the definition of calquing) are known as morphemes. Morphemes can, in turn, be rendered in two manners:

1. The source language (hence, $S L$ ) morphemes including prefixes may be rendered into lexemes in the TL. In this condition, it so appears that the TL words will most probably be compounds because the roots of words are also translated into lexemes mostly. In some cases, TL words might even be synthetic compounds.

2. The SL morphemes including affixes may be similarly translated into affixes in the TL. In this case, the TL words will normally be derivational.

Thus, it can be summarized that there are two UTs considered in termformation namely words and morphemes. In the former (called conceptual method), the focus is on the meaning of the whole word. In the latter type (called calquing), there are two outcomes for SL morphemes (prefixes in this study): being rendered into affixes (leading to derivatives) or lexemes (leading to compounds).

There is not a single criterion to distinguish affixes (prefixes in this study) from lexemes. Scholars have different views in this regard. However, in the present article, the viewpoint of Kalbasi (2008) was adopted as one of the modern definitions. According to her, prefixes are bound morphemes that precede bases and cannot be used independently. In other words, they should always be attached to other words or bases. On the other hand, lexemes can be used independently and do not need to be attached to other words or bases. For instance, 1 i is considered a prefix since it cannot be used alone, but بـرون is regarded as a lexeme since it can be used independently without being attached to other bases (see table 2). 


\section{Treating prefixes in term-formation}

As the focus of the current study, the researcher aims to find the ways terminologists treat prefixes in their translations of English terms. Based on the kinds of term-formation methods discussed above, it can be concluded that prefixes can be treated in three manners:

1. Prefix into Prefix: They may be translated into a prefix in Persian and the output would be a derivative. An example may be progression translated into يشروى (going forward).

2. Prefix into Lexeme: They may be translated into Persian as a Lexeme. Thus, the output would mostly be a compound. An example is projection translated into برونفكنى (throwing outside).

3. Ignoring Prefix (Focus on Function): The prefix may be ignored. Here, the focus would be on the function of the source word. Since the whole word rather than its constituents is observed here, the UT in this method is a word. An example may be projectile translated into برتابه (something that is thrown). Borrowing English words is also a case of ignoring prefixes. An example may be prostate translated into بروستات (/prosta:t/).

\section{Corpus of the study}

The present study used a general bilingual parallel corpus comprising an English element and a Persian one. English terms were listed next to their Persian equivalents. All the words with the specified prefixes were included and no randomization was applied in selecting them. The entries in the books follow an alphabetic order in both Persian and English. Since our ST is the collection of English words, the part alphabetized in English was adopted. The 
ABgarmI, R. P.; SHaghaghI, V. - Units of Translation Adopted in Persian Term-formation

corpus of the study comprised all the eleven volumes of the book A Collection of Terms: approved by the Academy of Persian Language and Literature published by APLL from 2004 to 2014.

Term-formation is officially conducted by the APLL in Iran. Thus, the above-mentioned book was selected as the corpus of study. Furthermore, we attempted to study the recent status of Persian term-formation. The chosen corpus is frequently updated and newer terms are continuously added to it through years. Perhaps, it would not be an exaggeration to call it the most up-to-date corpus of Persian equivalents offered for English terms. Some of the words in this corpus are not found in popular dictionaries or even on the Internet. Even when they are found, newer senses of them are not included. Instances might be the word off-peak hours meaning زمان سبكى or MMS translated into فرئيام .

Moreover, a digital corpus was also used beside the books. This digital corpus comprised all the eleven volumes of the books online. This corpus is accessible at: http://www.persianacademy.ir/fa/word/default.aspx.

\section{Procedures for data collection}

The present study was conducted on words or to be exact, terms, and the equivalents offered for them by APLL. Every word in the corpus containing the specified prefixes constituted the data for the study. Thus, 40 prefixes were examined, their list being extracted from English word-formation processes (LIEBER 2005). There are, for sure, many prefixes in English, but examining all of them were beyond the scope of the present study. Moreover, the 40 extracted prefixes were among the most common prefixes in English (see LEHRER 1995; BAUER 1983). They are given in alphabetical order in table 1. 
ABgarmI, R. P.; SHaghaghI, V. - Units of Translation Adopted in Persian Term-formation

The first step in data collection was to determine what English prefixes were to be analyzed in the study. Having extracted the list of prefixes, English words containing the specified prefixes were manually extracted from the corpus and categorized under each prefix. The equivalents offered by APLL for the selected words were also extracted from the same corpus. English words and their Persian equivalents were tabulated to make their comparison easier. The online corpus (the APLL official website tool) was used as an instrument to search prefixes in the corpus and yield concise results. Over 2354 words with the specified prefixes were found. The words were then extracted and classified in Microsoft Excel 2013. The frequencies of the prefixes in the corpus are given in table 1.

\begin{tabular}{|l|c|l|c|l|c|}
\hline \multicolumn{1}{|c|}{ Prefix } & Frequency & \multicolumn{1}{|c|}{ Prefix } & Frequency & \multicolumn{1}{c|}{ Prefix } & Frequency \\
\hline 01. after- & 36 & 15. extra- & 65 & 29. pre- & 671 \\
\hline 02. ante- & 105 & 16. fore- & 390 & 30. pro- & 1206 \\
\hline 03. anti- & 283 & 17. hyper- & 72 & 31. pseudo- & 37 \\
\hline 04. arch- & 240 & 18. inter- & 580 & 32. retro- & 41 \\
\hline 05. auto- & 173 & 19. meta- & 145 & 33. semi- & 98 \\
\hline 06. back- & 199 & 20. micro- & 171 & 34. sub- & 308 \\
\hline 07. bi- & 1433 & 21. mis- & 273 & 35. super- & 148 \\
\hline 08. by- & 102 & 22. multi- & 167 & 36. supra- & 26 \\
\hline 09. circum- & 10 & 23. non- & 230 & 37. trans- & 564 \\
\hline 10. counter- & 131 & 24. off- & 224 & 38. un- & 238 \\
\hline 11. dis- & 779 & 25. on- & 64 & 39. under- & 100 \\
\hline 12. down- & 94 & 26. out- & 306 & 40. up- & 73 \\
\hline 13. en- & 426 & 27. over- & 375 & & \\
\hline 14. ex- & 278 & 28. post- & 206 & & \\
\hline
\end{tabular}

Table 1 - Frequency of extracted prefixes 
ABgarmI, R. P.; SHaghaghI, V. - Units of Translation Adopted in Persian Term-formation

\section{Data classification}

Cells of the tables had to be highlighted in order to group words. As it was mentioned, prefixes were treated in three manners in offering Persian equivalents for English words, namely prefix into prefix, prefix into lexeme, and ignoring prefix. When conceptual equivalent-finding method is used (i.e. when UT is a word), the English prefixes are not translated separately. In these cases, the prefixes are ignored and no equivalents are identifiable for them. However, when calquing method is adopted (i.e. when UT is a morpheme), the prefixes are rendered into either prefixes or lexemes in Persian.

Highlighting was applied at this stage with multiple colors. Several colors were used to highlight words where the English prefix was translated into different prefixes in Persian. Other colors were also used to highlight instances of translating English prefixes into Persian lexemes. Finally, another color was employed to distinguish cases of conceptual equivalent-finding.

Following, a sample is presented of the way collected data were classified. The prefix extra- is selected as an instance (see table 2).

\begin{tabular}{|c|c|c|}
\hline SL Term & TL Equivalent & Prefix Equivalent \\
\hline extragalactic radiation & تابش فر اكهكثانى & Prefix \\
\hline extrasensory perception & ادر اك فر احسى & Prefix \\
\hline extraordinary ray & يرتوِ غير عادى & Prefix \\
\hline extra run & برنامئ اضافى & Lexeme \\
\hline extra chromosomal inheritance & ور اثت برونفاجتى & Lexeme \\
\hline extracellular & برونياختهاى & Lexeme \\
\hline extracronal retainer & نحكدارندة برونتاجى & Lexeme \\
\hline extramusical & برونموسيقابى & Lexeme \\
\hline extranet & برونِنت & Lexeme \\
\hline extranuclear inheritance & وراثت برونهستهاى & Lexeme \\
\hline extraoral orthodontic appliance & بَست آرتادندانى بروندهانى & Lexeme \\
\hline
\end{tabular}


ABgarmI, R. P.; SHaghaghI, V. - Units of Translation Adopted in Persian Term-formation

\begin{tabular}{|c|c|c|}
\hline SL Term & TL Equivalent & Prefix Equivalent \\
\hline extratropical cyclone & جرخند برونحارّهاى & Lexeme \\
\hline extraversion & برونيَر ايى & Lexeme \\
\hline trend extrapolation & برونيابى روند & Lexeme \\
\hline extra load tyre & تاير يُربار & Lexeme \\
\hline extra virgin olive oil & روغنزيتون بكر ممتاز & Lexeme \\
\hline extra-alveolar crown & ت تاج بالينى & Ignored \\
\hline extragalactic distance scale & نردبان فاصله & Ignored \\
\hline extrahepatic bile duct carcinoma & بوشجنحار زردابر اه & Ignored \\
\hline extraordinary felling & برش اضطر ارى & Ignored \\
\hline extrasystole & ضربان بيشرس & Ignored \\
\hline
\end{tabular}

Table 2 - A data classification sheet sample

It is noted that the prefix extra- is used in 21 words, but treated differently in each of them. The prefix equivalent column indicates how the prefix is treated in each word. When calquing method was adopted and the UT was a morpheme, the prefixes were translated into prefixes or lexemes. When the conceptual method was adopted, the UT was a word and the prefixes were ignored. The prefixes in highlighted cells are translated similarly.

For instance, the word extragalactic radiation is translated into تابش فراكهكشانى (belonging to over the galaxy) where the prefix extra- is translated into the prefix - فرا (over). The word extranet is translated into برونيت (outside the net) where extra- is translated into the lexeme برون (outside). Finally, extraordinary felling is translated into برش اضطرارى (emergency cutting) where the word ضطرارى (emergency) is offered as an equivalent for extraordinary, but no separate equivalent can be spotted for the prefix extra-. 
ABgarmI, R. P.; SHaghaghI, V. - Units of Translation Adopted in Persian Term-formation

\section{Results}

In the present study, the frequency of the two UTs, namely morpheme and word in Persian term-formation, was investigated. Following, the results are provided and the frequencies are calculated for both methods. The results are presented in two manners, general and detailed. The former indicates the sum of results for all 40 prefixes. However, the detailed results examine prefixes one by one, showing the mode (most frequent results) for them.

First, calquing, or analytic-compositional method, is finding equivalents for the constituting morphemes of words. In other words, the UT is a morpheme in this equivalent-finding method. In the present research, prefixes were studied as a subtype of morphemes. It was noted that English prefixes could be translated into either prefixes or lexemes in Persian. The results for each of them are presented in table 3.

\begin{tabular}{|c|c|c|c|c|c|c|c|c|c|c|c|c|c|c|}
\hline \multirow{2}{*}{$\mathrm{SL}^{\mathrm{TL}}$} & \multicolumn{4}{|c|}{ Prefix } & \multirow{2}{*}{ Sum } & \multicolumn{8}{|c|}{ Lexeme } & \multirow{2}{*}{ Sum } \\
\hline & $\mathrm{Eq}^{1}$ & $f^{2}$ & $\mathrm{Eq}$ & $f$ & & Eq & $f$ & Eq & $f$ & $\mathrm{Eq}$ & $f$ & $\mathrm{Eq}$ & $f$ & \\
\hline 1. after- & بֶ & 13 & باز & 1 & 14 & تكميلى & 1 & دوم & 1 & بيشإيسين & 1 & بعد & 1 & 4 \\
\hline \multirow{2}{*}{ 2. ante- } & بيش & 3 & بيشا & 3 & \multirow{2}{*}{7} & & & & & & & & & \multirow{2}{*}{0} \\
\hline & بِار & 1 & & & & & & & & & & & & \\
\hline \multirow{2}{*}{ 3. anti- } & بֶاد & 55 & ضد & 23 & \multirow{2}{*}{85} & بُر & 3 & كاه & 1 & كير & 1 & كزן & 1 & \multirow{2}{*}{8} \\
\hline & نا & 6 & و & 1 & & ستيز & 1 & زدا & 1 & & & & & \\
\hline 4. arch- & & & & & 0 & مجمع & 1 & بِر & 1 & & & & & 2 \\
\hline 5. auto- & & & & & 0 & خود & 48 & برجا & 2 & خود & 1 & & & 51 \\
\hline \multirow{2}{*}{ 6. back- } & بֶ & 18 & و & 3 & \multirow{2}{*}{23} & بركثت & 7 & بشت & 6 & عقب & 4 & بشت & 2 & \multirow{2}{*}{23} \\
\hline & يبش & 1 & باز & 1 & & بركردان & 1 & وارون & 1 & بشتشيان & 1 & ته & 1 & \\
\hline 7. bi- & & & & & 0 & دو & 52 & دوكانه & 2 & نيم & 1 & & & 55 \\
\hline 8. by- & & & & & 0 & ضمنى & 1 & جنبى & 1 & كنار & 1 & جانبى & 1 & 5 \\
\hline
\end{tabular}

\footnotetext{
${ }^{1}$ The abbreviation $E q$ stands for equivalent in all tables.

${ }^{2}$ The abbreviation $f$ stands for frequency in all tables.
} 
ABgarmI, R. P.; SHaghaghI, V. - Units of Translation Adopted in Persian Term-formation

\begin{tabular}{|c|c|c|c|c|c|c|c|c|c|c|c|c|c|c|}
\hline & & & & & & مياندورهاى & 1 & & & & & & & \\
\hline $\begin{array}{l}9 . \\
\text { circum- }\end{array}$ & بيرا & 1 & & & 1 & دور & 1 & & & & & & & 1 \\
\hline \multirow{2}{*}{$\begin{array}{l}10 . \\
\text { counter- }\end{array}$} & ياد & 15 & ضد & 9 & \multirow{2}{*}{27} & عكس & 2 & نقض & 1 & زدايى & 1 & وارون & 1 & \multirow{2}{*}{7} \\
\hline & دكر & 2 & نا & 1 & & مخالف & 1 & خلاف & 1 & & & & & \\
\hline \multirow{3}{*}{ 11. dis- } & نا & 16 & بى & 2 & \multirow{3}{*}{23} & زدايى & 4 & سلب & 1 & كم & 1 & خواه & 1 & \multirow{3}{*}{10} \\
\hline & g & 2 & دز & 1 & & كسيختحى & 1 & باخته & 1 & كز & 1 & & & \\
\hline & فرو & 1 & دكر & 1 & & & & & & & & & & \\
\hline \multirow{3}{*}{$\begin{array}{l}12 . \\
\text { down- }\end{array}$} & فرو & 13 & & & \multirow{3}{*}{14} & يايين & 5 & سو & 2 & راست & 1 & خواب & 1 & \multirow{3}{*}{14} \\
\hline & بيش & 1 & & & & بايين & 1 & زوج & 1 & آكار & 1 & يابه & 1 & \\
\hline & & & & & & افتاده & 1 & & & & & & & \\
\hline \multirow[t]{2}{*}{ 13. en- } & در & 1 & & & \multirow[t]{2}{*}{1} & سازى & 4 & كز ارى & 2 & در & 2 & بندى & 2 & \multirow[t]{2}{*}{13} \\
\hline & & & & & & كردن & 1 & دهى & 1 & انداز & 1 & & & \\
\hline \multirow{2}{*}{ 14. ex- } & دكر & 1 & بر & 1 & \multirow{2}{*}{4} & برون & 21 & ده & 1 & زدايى & 1 & بردارى & 1 & \multirow{2}{*}{25} \\
\hline & فرا & 1 & وا & 1 & & زا & 1 & & & & & & & \\
\hline $\begin{array}{l}15 . \\
\text { extra- }\end{array}$ & فرا & 2 & غير & 1 & 3 & برون & 10 & بهر & 1 & متاز & 1 & اضافى & 1 & 13 \\
\hline $\begin{array}{l}16 . \\
\text { fore- }\end{array}$ & بيش & 10 & يِيشا & 1 & 11 & آينده & 2 & بيشين & 1 & جلو & 1 & جلو & 1 & 5 \\
\hline \multirow{2}{*}{$\begin{array}{l}17 . \\
\text { hyper- }\end{array}$} & بيش & 11 & ابر & 3 & \multirow{2}{*}{19} & يقر & 6 & برين & 2 & افر اطى & 1 & دور & 1 & \multirow{2}{*}{10} \\
\hline & فوق & 3 & فرا & 2 & & & & & & & & & & \\
\hline \multirow{5}{*}{$\begin{array}{l}18 . \\
\text { inter- }\end{array}$} & هم & 4 & & & \multirow{5}{*}{7} & ميان & 27 & بين & 24 & در هم & 4 & جند & 3 & \multirow{5}{*}{76} \\
\hline & بينا & 3 & & & & بر & 2 & واسط & 2 & يايه & 2 & درون & 2 & \\
\hline & & & & & & متقابل & 1 & رابط & 1 & يبما & 1 & مرز & 1 & \\
\hline & & & & & & بساييشين & 1 & مخلوط & 1 & به هم & 1 & ميانجى & 1 & \\
\hline & & & & & & برهم & 1 & دو & 1 & & & & & \\
\hline \multirow{3}{*}{$\begin{array}{l}19 . \\
\text { meta- }\end{array}$} & دكر & 7 & فرا & 5 & \multirow{3}{*}{16} & متقابل & 1 & بـر & 1 & & & & & \multirow{3}{*}{2} \\
\hline & يس & 2 & در & 1 & & & & & & & & & & \\
\hline & شبه & 1 & & & & & & & & & & & & \\
\hline $\begin{array}{l}20 . \\
\text { micro- }\end{array}$ & فرا & 1 & & & 1 & ريز & 45 & خرد & 12 & كم & 3 & ميكرو & 1 & 61 \\
\hline 21. mis- & نا & 1 & دكر & 1 & 2 & كز & 2 & نامناسب & 1 & خطا & 1 & & & 4 \\
\hline \multirow{2}{*}{$\begin{array}{l}22 . \\
\text { multi- }\end{array}$} & هم & 2 & جندا & 2 & \multirow{2}{*}{5} & جند & 42 & بس & 2 & جندم & 2 & مكرر & 1 & \multirow{2}{*}{48} \\
\hline & بيش & 1 & & & & دو & 1 & & & & & & & \\
\hline
\end{tabular}


ABgarmI, R. P.; SHaghaghI, V. - Units of Translation Adopted in Persian Term-formation

\begin{tabular}{|c|c|c|c|c|c|c|c|c|c|c|c|c|c|c|}
\hline \multirow{2}{*}{ 23. non- } & نا & 44 & غير & 33 & \multirow{2}{*}{88} & عدم & 2 & بدون & 1 & فاقد & 1 & سلب & 1 & \multirow{2}{*}{6} \\
\hline & بى & 9 & ن & 2 & & برون & 1 & & & & & & & \\
\hline \multirow{2}{*}{ 24. off- } & يِ & 2 & فرا & 1 & \multirow{2}{*}{5} & برون & 5 & كثتنه & 4 & خار ج از & 2 & بيرونى & 1 & \multirow{2}{*}{16} \\
\hline & غير & 1 & بى & 1 & & دور & 1 & خارج & 1 & كج & 1 & بايان & 1 & \\
\hline \multirow{2}{*}{ 25. on- } & با & 1 & & & \multirow{2}{*}{2} & آغاز & 1 & سو & 1 & در & 1 & به & 1 & \multirow{2}{*}{6} \\
\hline & بر & 1 & & & & روى & 1 & بر & 1 & & & & & \\
\hline \multirow{2}{*}{ 26. out- } & بر & 1 & & & \multirow{2}{*}{1} & برون & 7 & دور & 2 & بيى & 1 & دريا & 1 & \multirow{2}{*}{13} \\
\hline & & & & & & بيرون & 1 & ردى & 1 & & & & & \\
\hline \multirow{3}{*}{$\begin{array}{l}27 . \\
\text { over- }\end{array}$} & بيش & 19 & فرا & 3 & \multirow{3}{*}{23} & اضافه & 3 & مفرط & 2 & اضافه & 1 & بيشبود & 1 & \multirow{3}{*}{15} \\
\hline & بيش & 1 & & & & رو & 1 & تتد & 1 & بيشازحد & 1 & اضافى & 1 & \\
\hline & & & & & & سر & 1 & زياد & 1 & ير & 1 & بر & 1 & \\
\hline $\begin{array}{l}28 . \\
\text { post- }\end{array}$ & بِ & 15 & بِّا & 13 & 28 & ن ناكذر & 1 & بِ از & 1 & يشت & 1 & & & 3 \\
\hline \multirow{3}{*}{ 29. pre- } & بيش & 60 & بيشا & 6 & \multirow{3}{*}{67} & يِش از & 6 & زود & 3 & مقدماتى & 1 & سر & 1 & \multirow{3}{*}{16} \\
\hline & فرا & 1 & & & & كمى & 1 & نوك & 1 & بيشبينى & 1 & كوجى & 1 & \\
\hline & & & & & & تقديمى & 1 & & & & & & & \\
\hline \multirow{3}{*}{ 30. pro- } & بيش & 30 & فرا & 4 & \multirow{3}{*}{40} & برون & 2 & آينده & 1 & دومرحلهاى & 1 & يجى & 1 & \multirow{3}{*}{7} \\
\hline & بر & 3 & فرو & 2 & & آغازين & 1 & بيرون & 1 & & & & & \\
\hline & بيشّا & 1 & & & & & & & & & & & & \\
\hline $\begin{array}{l}31 . \\
\text { pseudo- }\end{array}$ & شبه & 12 & & & 12 & نما & 6 & كاذب & 3 & دروغين & 1 & بس & 1 & 11 \\
\hline \multirow{2}{*}{$\begin{array}{l}32 . \\
\text { retro- }\end{array}$} & يس & 8 & وا & 2 & \multirow{2}{*}{11} & بركثنى & 1 & عقب & 1 & يشت & 1 & كذنته & 1 & \multirow{2}{*}{4} \\
\hline & بر & 1 & & & & & & & & & & & & \\
\hline $\begin{array}{l}33 . \\
\text { semi- }\end{array}$ & شبه & 1 & & & 1 & نيم & 27 & نيمه & 19 & & & & & 46 \\
\hline \multirow{3}{*}{ 34. sub- } & فرو & 8 & وا & 3 & \multirow{3}{*}{15} & زير & 48 & نيمه & 7 & جنب & 5 & جا & 4 & \\
\hline & دكر & 1 & شبه & 1 & & خرده & 2 & فرعى & 2 & تحت & 1 & نيم & 1 & 74 \\
\hline & بر & 1 & بِ & 1 & & زيرين & 1 & يايين & 1 & دوم & 1 & بيى & 1 & \\
\hline & ابر & 28 & فرا & 6 & & بر هم & 2 & زبر & 2 & افر اطى & 1 & ثانويه & 1 & \\
\hline $\begin{array}{l}\text { SJ. } \\
\text { super- }\end{array}$ & بر & 1 & باز & 1 & 36 & برتز & 1 & بسيار & 1 & تتد & 1 & سر & 1 & 12 \\
\hline & & & & & & تركيبى & 1 & رو & 1 & & & & & \\
\hline 36. & فرا & 1 & فوق & 1 & 3 & بالا & 5 & زبر & 2 & بر & 1 & بالايى & 1 & 10 \\
\hline supra- & ابر & 1 & & & & تك & 1 & & & & & & & \\
\hline 37. & ترا & 37 & ورا & 2 & 42 & تر انس & 3 & كردانى & 2 & نيم & 1 & Los & 1 & 8 \\
\hline
\end{tabular}


ABgarmI, R. P.; SHaghaghI, V. - Units of Translation Adopted in Persian Term-formation

\begin{tabular}{|c|c|c|c|c|c|c|c|c|c|c|c|c|c|c|}
\hline trans- & فرا & 2 & دكر & 1 & & رو & 1 & & & & & & & \\
\hline \multirow{2}{*}{ 38. un- } & نا & 25 & ن & 11 & \multirow{2}{*}{51} & عدم & 1 & & & & & & & \multirow{2}{*}{1} \\
\hline & بى & 10 & غير & 5 & & & & & & & & & & \\
\hline \multirow{3}{*}{$\begin{array}{l}39 . \\
\text { under- }\end{array}$} & نا & 1 & & & \multirow{3}{*}{2} & زير & 14 & كم & 7 & كمبود & 2 & كسر & 2 & \multirow{3}{*}{33} \\
\hline & فرو & 1 & & & & كف & 1 & فرود & 1 & زيرين & 1 & در & 1 & \\
\hline & & & & & & كم & 1 & بن & 1 & ناكافى & 1 & كند & 1 & \\
\hline \multirow{2}{*}{ 40. up- } & فرا & 11 & لياد & 2 & \multirow{2}{*}{15} & بالا & 8 & به كار & 1 & جֶ! & 1 & بعد & 1 & \multirow{2}{*}{14} \\
\hline & بيش & 1 & بـ & 1 & & فرد & 1 & كار ايى & 1 & افز ايى & 1 & & & \\
\hline Total & & & & & 705 & & & & & & & & & 732 \\
\hline
\end{tabular}

Table 3 - Morpheme as UT

In table 3, 40 English prefixes are listed as SL Prefixes. Their extracted TL equivalents are portrayed in two separate columns in front of them. The first column includes those equivalents that are similarly considered prefixes in Persian. The second column comprises the equivalents considered lexemes in Persian. Moreover, two columns are used to showing the sum of TL prefixes and lexemes for each SL prefix.

Each of the prefix or lexeme equivalents is followed by its frequency. For instances, for the first SL prefix (after-), the TL prefix equivalent - is offered in 13 cases while the TL prefix - باز (meaning re-) is offered in one case. Moreover, some equivalents are considered lexemes including تكعيلى، دوم، (meaning complementary, second, succeeding, and then respectively). Each of these equivalents is employed once. Finally, the sum columns indicate that the prefix after- is translated into Persian prefixes in 14 cases while being translated into Persian lexemes in 4 cases. The final row also shows the total cases of translating SL prefixes into TL prefixes or lexemes. In sum, calquing method was used in 1437 words.

Second, in conceptual equivalent-finding, equivalents are offered regardless of the structure of the SL words. Instead, the meaning of the whole word is used as UT in equivalent-finding. Thus, unlike calquing method, 
ABgarmI, R. P.; SHaghaghI, V. - Units of Translation Adopted in Persian Term-formation

separate equivalents are not identifiable for SL prefixes. Table 4 shows the frequency of this method used for each of the 40 prefixes studied.

\begin{tabular}{|l|c|l|c|l|c|l|c|}
\hline \multicolumn{1}{|c|}{ SL Prefix } & F & \multicolumn{1}{|c|}{ SL Prefix } & F & \multicolumn{1}{|c|}{ SL Prefix } & F & \multicolumn{1}{|c|}{ SL Prefix } & F \\
\hline 1. after- & 1 & 11. dis- & 38 & 21. mis- & 3 & 31. pseudo- & 1 \\
\hline 2. ante- & 4 & 12. down- & 4 & 22. multi- & 21 & 32. retro- & 4 \\
\hline 3. anti- & 11 & 13. en- & 42 & 23. non- & 24 & 33. semi- & 7 \\
\hline 4. arch- & 2 & 14. ex- & 144 & 24. off- & 10 & 34. sub- & 35 \\
\hline 5. auto- & 14 & 15. extra- & 5 & 25. on- & 7 & 35. super- & 17 \\
\hline 6. back- & 13 & 16. fore- & 8 & 26. out- & 18 & 36. supra- & 0 \\
\hline 7. bi- & 14 & 17. hyper- & 5 & 27. over- & 4 & 37. trans- & 98 \\
\hline 8. by- & 0 & 18. inter- & 77 & 28. post- & 9 & 38. un- & 14 \\
\hline 9. circum- & 4 & 19. meta- & 6 & 29. pre- & 74 & 39. under- & 11 \\
\hline 10. counter- & 4 & 20. micro- & 13 & 30. pro- & 138 & 40. up- & 13 \\
\hline \multicolumn{7}{|c|}{ Sum } & \multicolumn{7}{|c|}{917} & \\
\hline
\end{tabular}

Table 4 - Word as UT

In table 4, each prefix is followed by a number in frequency columns. This number shows the frequency of conceptual equivalent-finding used for each of the prefixes. Since in this method the equivalents are offered for the whole word rather than its constituting morphemes, no equivalent is given here. In sum, 917 words were translated using the conceptual method.

With respect to the two methods and the tables offered above, the following results were obtained (see figure 1). 
ABGaRMI, R. P.; ShaghaghI, V. - Units of Translation Adopted in Persian Term-formation

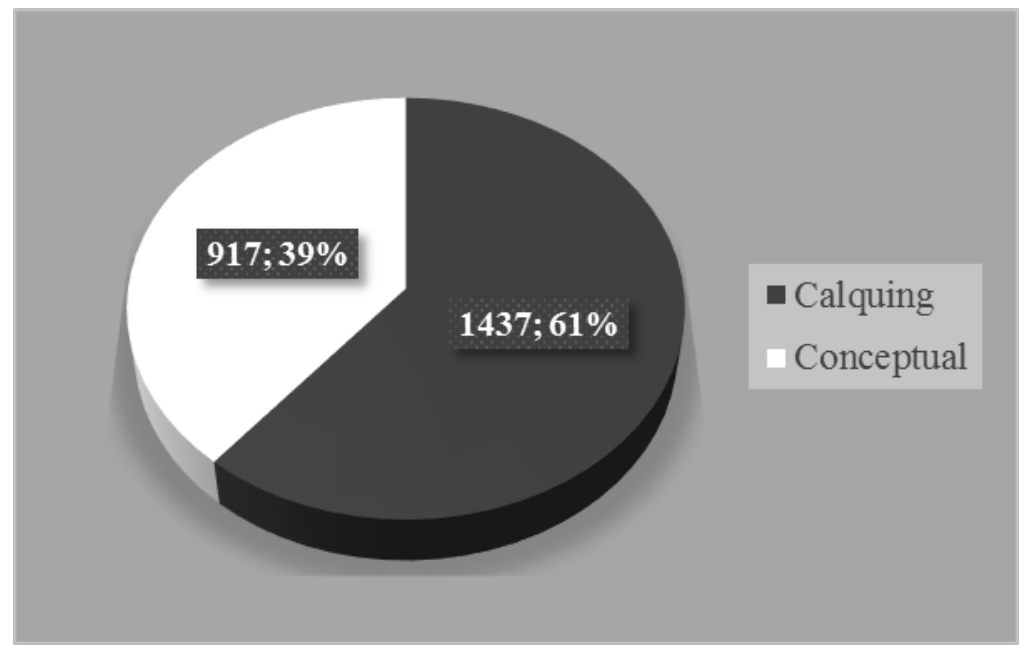

Figure 1 - Calquing vs. Conceptual

It can be noticed that calquing is used more frequently in equivalentfinding methods adopted by the APLL. Calquing is used in finding equivalents for 1437 words. These words constitute $61 \%$ of the whole studied words. Moreover, conceptual equivalent-finding was used to find equivalents for 917 words, constituting $39 \%$ of them.

The above-mentioned graph was used to compare the equivalentfinding methods in general. However, a more detailed comparison can be drawn for each SL prefix (see figure 2):

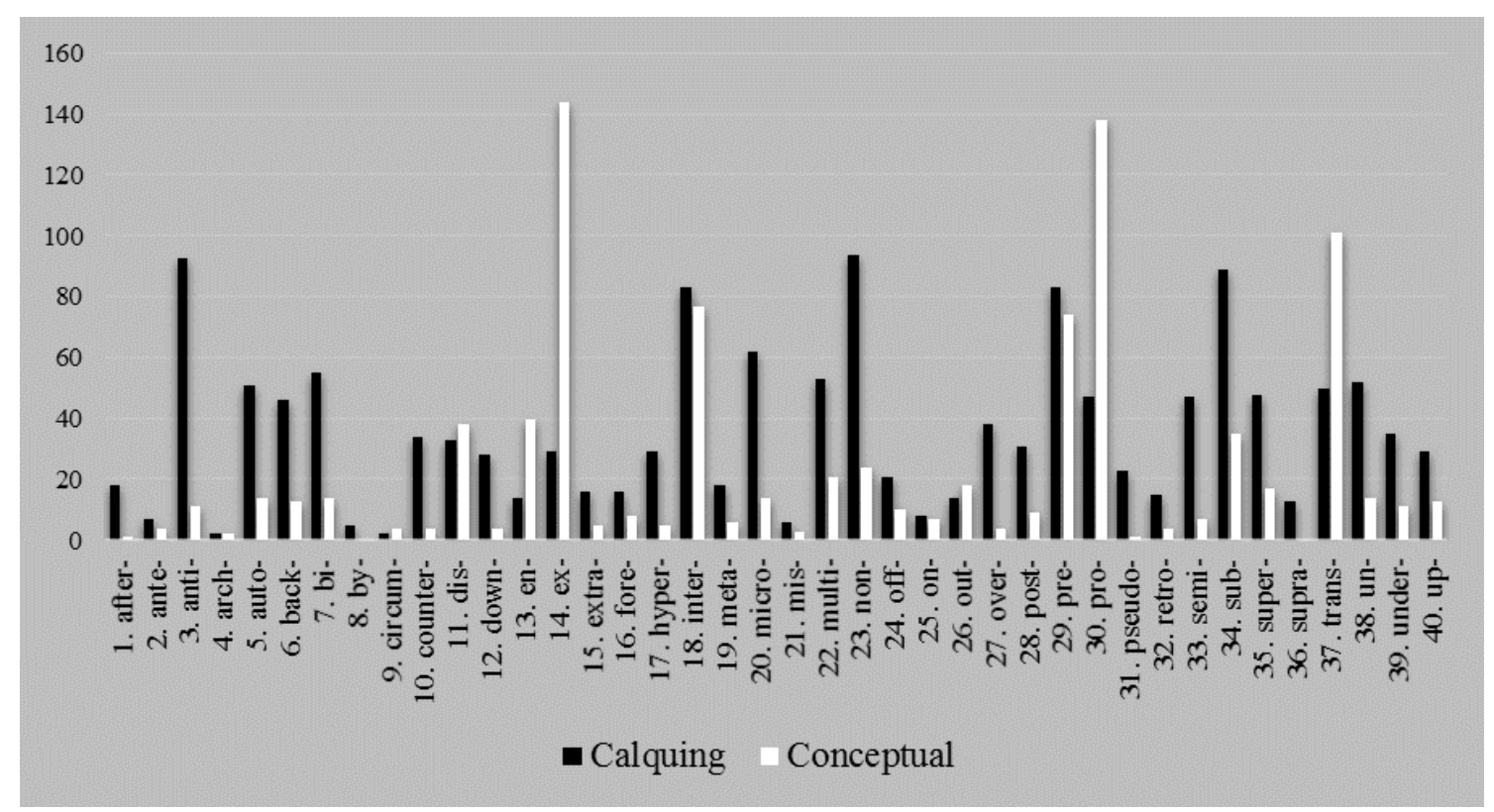

TradTerm, São Paulo, v. 29, Junho/2017, p. XX-XX www.usp.br/tradterm 
ABgarmI, R. P.; SHaghaghI, V. - Units of Translation Adopted in Persian Term-formation

Figure 2 - Calquing vs. Conceptual

In 32 cases, constituting $80 \%$ of words, calquing method was more favored. However, in seven instances, equal to $18 \%$ of words, conceptual method was more frequent. In one case, the number of calquing was equal to conceptual method.

\section{Findings and discussion of the results}

The present study investigated the frequency of two term-formation methods, namely structural (or calquing) and conceptual. Calquing was used in 1437 cases (61\%) while conceptual equivalent-finding was applied in 917 cases (39\%). This indeed supports what was suggested by Tajvidi (2005), that analytic-compositional method has been the most frequent equivalent-finding strategy in recent decades. The results for each of the English prefixes are even more markedly contrastive. The most frequent equivalents (the modes) were formed structurally in $80 \%$ of cases while they were produced through conceptual method merely in $18 \%$ of cases.

The higher frequency of calquing sheds light on another issue. It shows that morphemes are more frequently considered UTs in Persian termformation than words. This is indeed a counterexample of what was discussed in the background section that smaller UTs are generally neglected. It can be resolved that smaller UTs are adopted in areas such as term-formation and perhaps continue to be.

\section{Conclusions}


ABgarmI, R. P.; SHaghaghI, V. - Units of Translation Adopted in Persian Term-formation

As a summary, the present study dealt with the UTs adopted in Persian term-formation and their frequencies. It was noted that calquing or structural analysis of words was more frequent than conceptual equivalent-finding. This means that smaller UTs (e.g. morphemes) seem to be more favored by APLL in finding equivalents for SL terms than conceptual equivalent-finding (when UT is the whole word). Moreover, in calquing, the amount of translating prefixes into prefixes or lexemes was very close. Consequently, derivation and compounding were close.

When it comes to the higher frequency of calquing, it can be concluded that the current norm in term-formation is structural analysis of words. This might be interpreted in another way. Calquing involves focusing on smaller UTs such as morphemes. However, in the conceptual method, the whole word is the UT. Therefore, it might be claimed that the terminologist's higher preference for calquing is related to their analytic personality. As noted by Dewey (2004), analytic types of characters pay attention to the parts (morphemes here) while holistic ones see something as a whole (the whole word here), not a collection of parts. Therefore, for instance, holistic people might choose UTs at higher ranks while analytic people may analyze words morpheme by morpheme. As a suggestion for further research, conducting a correlative study on the relation between holistic or analytic personality and the adopted UT is recommended.

\section{References}

BADAWI, Abdurrahman. "The Way of Hellenizers: The Transmission of Greek Philosophy to Islamic Civilization". In: Genealogy of Translation in Iran, edited by Hussein Mollanazar, 93-104. Tehran: Allameh Tabataba' $i$ University, 1986. 
ABgarmI, R. P.; SHaghaghI, V. - Units of Translation Adopted in Persian Term-formation

BAUER, Laurie. English word-formation. New York: Cambridge University Press, 1983.

DeweY, A. Introduction to Psychology. $1^{\text {st }}$ ed. Boston: Wadsworth Publishing, 2004.

KALBASI, Iran. The derivational structure of word in modern Persian. Tehran: Institute for Humanities and Cultural Studies, 2008.

KHODABAKHSHI, Morteza. "A comparative-contrastive study of the second termformation process adopted by the first and third academics of Persian Language and Letters". Master's thesis. Tehran: Allameh Tabataba'i University, 2009.

LEHRER, Adrienne. "Prefixes in English Word Formation". In: Folia Linguistica 29 (1-2), 1995. p. 133-148.

LIEBER, Rochelle. "English word-formation processes". In: Handbook of wordformation, edited by Pavol Stekauer and Rochelle Lieber. The Netherlands: Springer, 2005. p. 375-427.

MundaY, Jeremy. Introducing Translation Studies. $2^{\text {nd }}$ ed. Canada: Routledge, 2008.

PASHA ABGARMI, Rasool. "Affix as a Unit of Translation: A case study of the translation of prefixes by the Academy of Persian Language and Literature (APLL)". Master's thesis. Tehran: Allameh Tabataba'i University, 2015.

SAger, J. C. A Practical Course in Terminology Processing. Amsterdam: John Benjamins Publishing Company, 1990.

ShUtTleworth, Mark, and Moira Cowie. Dictionary of Translation Studies. Manchester: St Jerome Publishing, 1997.

Terminology Department. A Collection of Terms: approved by the Academy of Persian Language and Literature (vol. 1-11). Tehran: The academy of Persian language and literature, 2004-2014.

TAJVIDI, Gholamreza. English morphology plus word-formation processes in English \& Persian. Tehran: SAMT, 2005. 
ABgarmI, R. P.; SHaghaghI, V. - Units of Translation Adopted in Persian Term-formation

YULE, George. The study of language. $4^{\text {th }}$ ed. New York: Cambridge University Press, 2010.

Data de submissão: $27 / 04 / 2016$

Data de aprovação: 17/02/2017

TradTerm, São Paulo, v. 29, Julho/2017, p. 146-167 www.usp.br/tradterm 